\title{
A proposed conceptual familiness* transmission of capital model
}

\author{
W.P. Venter \\ Allied Electronics Corporation Ltd, 4 Sherbourne Road, \\ Parktown 2193, Republic of South Africa \\ jmorris@altron.co.za \\ S. Kruger** \\ Faculty of Management, University of Johannesburg, PO Box 524, \\ Auckland Park 2006, , Republic of South Africa \\ stephenk@uj.ac.za \\ F.J. Herbst \\ University of Stellenbosch Business, \\ PO Box 610 Bellville 7535, Republic of South Africa \\ fjh@usb.sun.ac.
}

Received July 2007

\begin{abstract}
Notwithstanding family businesses being a prevalent phenomenon in the economies of most countries, insight into this form of enterprise is still limited and it has been largely ignored as a study field. Interest has now grown in identifying and understanding those facets of business that support the superior performance of family firms. As interest in the field of family business has expanded, so have the theories that support these views. Theory therefore provides a guideline to investigate causalities and link information. It indicate that presently there is no single, generally accepted theory defining the family-firm concept and that rigorous work on such theory is only just starting.
\end{abstract}

\begin{abstract}
The purpose of this article is to review the different theories underlying family businesses. It is concluded that the orthodox theories, that regard the business and the family as separate units, do not acknowledge the complexity of the different relationships that exist in family businesses. A Conceptual Familiness Transmission of Capital Model is suggested in the current study as representative of the functioning of family businesses as an interactive system. It embraces the heterodox views that the family and the business cannot be separated, but are rather seen as an interactive system with unique, collectable resources. It fulfils the need of the main deficiency in the family organisation literature, namely a theory that explains the developmental stages of each generation succession.
\end{abstract}

*Used in the context of Habbershon and Williams (1999:1)

**To whom all correspondence should be addressed.

\section{Introduction}

Notwithstanding family businesses being a prevalent phenomenon in the economies of most countries, insight into this form of enterprise is still limited and it has been largely ignored as a study field (Litz, 1997:55-57). Various reasons are offered for the lack of research, mainly because family businesses were seen as dysfunctional entities by historians since the 1950s (Litz, 1997:57-63). This is further explained by Kepner (1983:57-58) who postulates that research into family businesses was done at a time when North Americans saw the combination of individualism, efficiency and objective management as the principal factors of corporate success. Even the dreary performance of French and British economies was blamed by historians like Landes (1965:275) and Chandler (1990:14, 46 \& 389-392) on the lacklustre role that family firms played in these economies (Church, 1993:17-19).

Interest has now grown in identifying and understanding those facets of business that support the superior performance of family firms. Liang and Jek (2000:14-15), for example confirm that founder competence and family cohesion, in combination, lead to family-firm business growth. Similarly, Anderson and Reeb (2003:17-23) indicate from a study of 500 Standard and Poors (S\&P) USA firms, that family businesses are more likely to outperform non-family businesses when the founder and family members are in Chief Executive Officer's positions. Gilmour (2005:1) reports that the family business with the best track-record in South Africa, is Pick ' $n$ Pay, in that it complies with the criteria given by the US-based Mass Mutual Financial Group and Raymond Institute as reasons for the superior performance of large family businesses, namely:

- Avoidance of debt

- Being future orientated 
- Run by families indicating that they want to retain control, implying their care for the destiny of the company; and

- Showing optimism about the future

\section{Family business theories}

As interest in the field of family business has expanded, so have the theories that support the views of superior performance. Theory therefore provides a guideline to investigate causalities and link information. Chrisman, Chua and Sharma (2003:32) indicate that presently there is no single, generally accepted theory defining the family-firm concept and that rigorous work on such theory is only just starting.

While the earlier theories describe the family and the firm as separate entities, the more recent perceptions acknowledge the reciprocal, inseparable relationship that exists between the family and the business. A summary on the family business theories is shown in Table 1 .

Table 1: Summary of family business theories

\begin{tabular}{|c|c|}
\hline Family business theories & Brief description \\
\hline \multicolumn{2}{|l|}{ 1. Earlier orthodox theories: } \\
\hline $\begin{array}{l}\text { - The two-circle model of family } \\
\text { businesses }\end{array}$ & Differentiate among the family and business (Lansberg, 1983:44). \\
\hline $\begin{array}{l}\text { - Three circle model of family } \\
\text { businesses }\end{array}$ & Differentiates among owners, management and family members (Tagiuri \& Davis, 1996:200). \\
\hline $\begin{array}{l}\text { - The development model of family } \\
\text { businesses }\end{array}$ & $\begin{array}{l}\text { Three dimensions of ownership, family and business are constantly changing and that change in } \\
\text { one dimension would bring about change in another dimension (Gersick, Davis, Hampton \& } \\
\text { Lansberg, 1997:17 \& 29). }\end{array}$ \\
\hline $\begin{array}{l}\text { - The ‘tie-version’ overlap model of } \\
\text { family businesses }\end{array}$ & $\begin{array}{l}\text { Neubauer and Lank (1998:15) identified the need for depicting the influence for governance } \\
\text { issues and added the 'board of directors' to the three-circle model. Fourteen different } \\
\text { combinations of possible roles in the family business were proposed. }\end{array}$ \\
\hline - The parallel planning process & $\begin{array}{l}\text { Carlock and Ward (2001:12) propose a parallel planning process of the good-bad family } \\
\text { business approach. It should serve as a viable guideline for constantly balancing family and } \\
\text { business concerns. }\end{array}$ \\
\hline - The family business hard-core model & $\begin{array}{l}\text { According to this model, a family firm has formalised and non-formalised core values and } \\
\text { principles. Bornheim's conclusion (2000:148) regarding the family business as a holistic system } \\
\text { is a move in the direction of the heterodox theories that interpret the family and the business as } \\
\text { a systemic-functioning structure. }\end{array}$ \\
\hline \multicolumn{2}{|l|}{ 2. Heterodox theories: } \\
\hline - The co-evolution theory & $\begin{array}{l}\text { Kepner (1983:57-70) indicates that there is a reciprocal, co-creational process between the } \\
\text { family and the business: the family creates the business and vice versa, implying therefore a } \\
\text { total system that cannot be separated into units. }\end{array}$ \\
\hline $\begin{array}{l}\text { - } \quad \text { The field theory } \\
\text {. }\end{array}$ & $\begin{array}{l}\text { Riordan and Riordan (1993:66-78) use the field theory to explain the collective processes that } \\
\text { take place in the family firm. The field-theory originated from physical sciences. It was applied } \\
\text { in management by Argyris (1953) and to social sciences by Lewin (1997). In principle, the } \\
\text { field-theory implies that phenomena cannot be explained or examined without exploring the } \\
\text { entirety of interactions among the different elements. }\end{array}$ \\
\hline 3. The living company & $\begin{array}{l}\text { The term 'living company' was coined by De Geus (1997:5) to refer to any form of business } \\
\text { with an exceptional longevity. De Geus (1997) indicates that the average life-span of a firm } \\
\text { (not just family firms) is twenty-nine years, while living companies usually last for several } \\
\text { generations. It is explained that definite differences in the philosophies and approaches of living } \\
\text { and non-living companies could relate to variations in longevity. Kreiser (2001:10) draws a } \\
\text { comparison between family businesses and living companies, arguing that, on average, family } \\
\text { businesses show longer tenure than non-family businesses. }\end{array}$ \\
\hline $\begin{array}{l}\text { 4. The unified systems model of } \\
\text { familiness }\end{array}$ & $\begin{array}{l}\text { Habbershon, Williams and Macmillan (2001:10-15) propagates an advanced, unified-systems } \\
\text { model, acknowledging a continuous flow of feedback and influence in the family business } \\
\text { rather than a degree of overlapping between family and business as suggested by the orthodox } \\
\text { models. }\end{array}$ \\
\hline $\begin{array}{l}\text { 5. Borrowed theories from Chrisman, } \\
\text { Chua and Sharma (2003b) }\end{array}$ & $\begin{array}{l}\text { - Agency theory: Agency theory relates to the investigation of non-owner managers, regarded } \\
\text { as agents, who would possibly not be as diligent in management tasks as the owner would } \\
\text { (Chrisman, Chua \& Litz, 2004:335 and Chua, Chrisman \& Sharma, 2003:97). } \\
\text { - The resource-based view of the family business (RBV): Chrisman et al. (2003:20-25) state } \\
\text { that the resource-based view should be used when the family business is investigated as an } \\
\text { entity with a leading competitive advantage. The resource-based view can be considered as } \\
\text { the combination of the financial and non-financial resources of the family business. }\end{array}$ \\
\hline
\end{tabular}


Gersick et al. (1997:17) found these theories too static and introduced a 'developmental' model. This has an additional time dimension that continuously changes, with different facets of the business, family and ownership engineering those changes. Habbershon et al. (2001:7-9) warn that, while the traditional models, explaining the nature of family businesses, introduce the individual to the complexities of family businesses. These perceptions could for the following reasons, negatively influence perceptions concerning the family firms:

- $\quad$ Overlap models and the core-business approach seem to support the good-bad approach, creating the impression that family and business can and should be separated, and that the family should be tolerated as non-influential in business performance. This is in contrast to certain studies that business and family is inseparable.

- $\quad$ The traditional models could also give the impression that 'triggers' are the drivers of change, and that strategic planning is a mere reaction in seeking an

- $\quad$ equilibrium. However, family-business performance should rather be seen as a dynamic process, not just a reaction on a trigger.

- The impression could follow from the traditional orthodox models that family-business performance is reached through compromise and balance-seeking, rather than the synthesis sought by high-performance firms.

- $\quad$ The traditional models can create the impression that the boundaries between the family and the business are to be managed to prevent conflict, leading to an inward focus, while preventing an outward focus of the dynamics of a fast-changing environment.

Though traditional models have proved to be useful in the earlier understanding of family businesses, the analyses indicate that family businesses are entities that need to be tolerated and that a survival attitude should be taken. Different heterodox theorists (i.e. Chrisman et al., 2003:2025; De Geus, 1997:5; Habbershon \& Williams, 1999:1-38; Kepner, 1983:57-70; Riordan \& Riordan, 1993:66-78 and Venter, 2003) challenge these orthodox, mainstream, family-business theories that consider the family and the business as separate, almost opposing the different heterodox theories.

Chrisman et al. (2003:20-25) however, viewed the family and the business as being inseparable, but simultaneously argue that the theories employed for the investigation into the family business, will depend on the aim of the investigation. Chrisman et al. (2003:20-25) therefore do not produce a new theory for family-firm investigation, but argue that both the latest agency and resource-based theories of business research can be applied in the investigation of family businesses.

Acknowledging the unique resources that the founder and the family bring to the family business, Venter (2003:79 \& 98-100) introduced the concepts of founder-, family- and generation-capital in a Familiness Transmission of Capital Model. The argument follows that founder-, family- and generation-capital can be seen as an important part of a family firm's human capital. Founder-, family- and generation-capital are identified as important resources that should lead to the superior performance.

The concept of founder-capital was inspired by Erikson's viewpoint (2002:275-278). Entrepreneurial capital is described as the infinite series of possible shadow options of entrepreneurial involvement by an individual that establishes a prevailing value of anticipated entrepreneurial behaviour. As shadow options are converted into proper options, entrepreneurial capital is formed. A synergy is created when the entrepreneurial capital of the firm is challenged, which in turn leads to entrepreneurial capital becoming available, thereby advancing the firm's performance (Erikson, 2002:279). For analytical clarity, the founder, the family and the consecutive generations are seen as resources of the family business, consisting of foundercapital, family-capital and generation-capital. Where founder-capital refers to the founder as a resource, familycapital refers to the children of the founder as a resource, while generation-capital refers to the descendants of the siblings as a resource. It is argued that founder-, family- and generation-capital of the enterprising family contribute to the familiness of a family business.

\section{Methodology of the article}

The study evolved from a qualitative format and included certain quantitative research elements. The analysis of the data by means of content analysis from the literature and interviews was aimed at answering the initial research question that was set out to fulfil the objectives of the study. The study followed a descriptive investigation followed by interviews, and data analysis of a sample of South African business groups within (Altron: Allied Electronics Corporation Limited). This investigation was done in relationship with the Familiness Transmission of Capital Model as suggested by Venter (2003:9-12). The idea was to explore the existence or non-existence of familiness in familiy-business groups in South-Africa and the role it plays in generation-transition of family businesses. Because of sensitivities in relation to the research, the identification of the participants was kept confidential. A sample was drawn from eight family-business groups in nine different industries, ranging from retail to winery, as depicted in Table 2. 
Table 2: Types of businesses the family business groups are involved in

\begin{tabular}{|c|c|c|c|c|c|c|c|c|c|c|}
\hline Participant & 䒕 & مo & 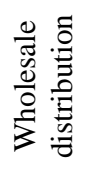 & 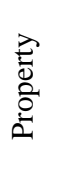 & 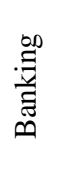 & 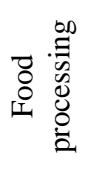 & 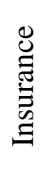 & $\stackrel{\infty}{.} \underset{\Xi}{.}$ & $\stackrel{\overrightarrow{0}}{\stackrel{B}{3}}$ & Total no of businesses \\
\hline 1 & $\sqrt{ }$ & $\sqrt{ }$ & $\sqrt{ }$ & & & & & & & 3 \\
\hline 2 & $\sqrt{ }$ & & & $\sqrt{ }$ & & & & $\sqrt{ }$ & & 3 \\
\hline 3 & $\sqrt{ }$ & & & $\sqrt{ }$ & & & & & & 2 \\
\hline 4 & $\sqrt{ }$ & $\sqrt{ }$ & $\sqrt{ }$ & & & & & & & 3 \\
\hline 5 & $\sqrt{ }$ & $\sqrt{ }$ & $\sqrt{ }$ & & & $\sqrt{ }$ & $\sqrt{ }$ & & & 5 \\
\hline 6 & & & & $\sqrt{ }$ & & & & & & 1 \\
\hline 7 & $\sqrt{ }$ & $\sqrt{ }$ & & $\sqrt{ }$ & & & & & & 3 \\
\hline 8 & $\sqrt{ }$ & $\sqrt{ }$ & & $\sqrt{ }$ & $\sqrt{ }$ & & & & $\sqrt{ }$ & 5 \\
\hline Total & 7 & 5 & 3 & 5 & 1 & 1 & 1 & 1 & 1 & 25 \\
\hline
\end{tabular}

The Venter Transmission of Capital Familiness Model

The Venter (2003:98-100) model, shown in Figure 1 indicates how familiness is ypothetically created, sustained and transmitted through the family-capital. Family-capital, which is created by the founder, is seen as a unique strength of family businesses. Venter (2003:85) refers to the combination of founder-, family- and generation-capital underlying familiness, as it is defined by Habbershon and
Williams (1999:17), namely: ‘...the unique bundle of resources a particular firm has because of the interaction between the family, its individual members, and the business.' Venter (2003:98-100) uses this familiness concept in family business as introduced by Habbershon and Williams (1999:17), as well as the resource-based view, to explain and investigate three different stages of generational succession. The three generation stages of the family business envisaged are represented in Figure 1.

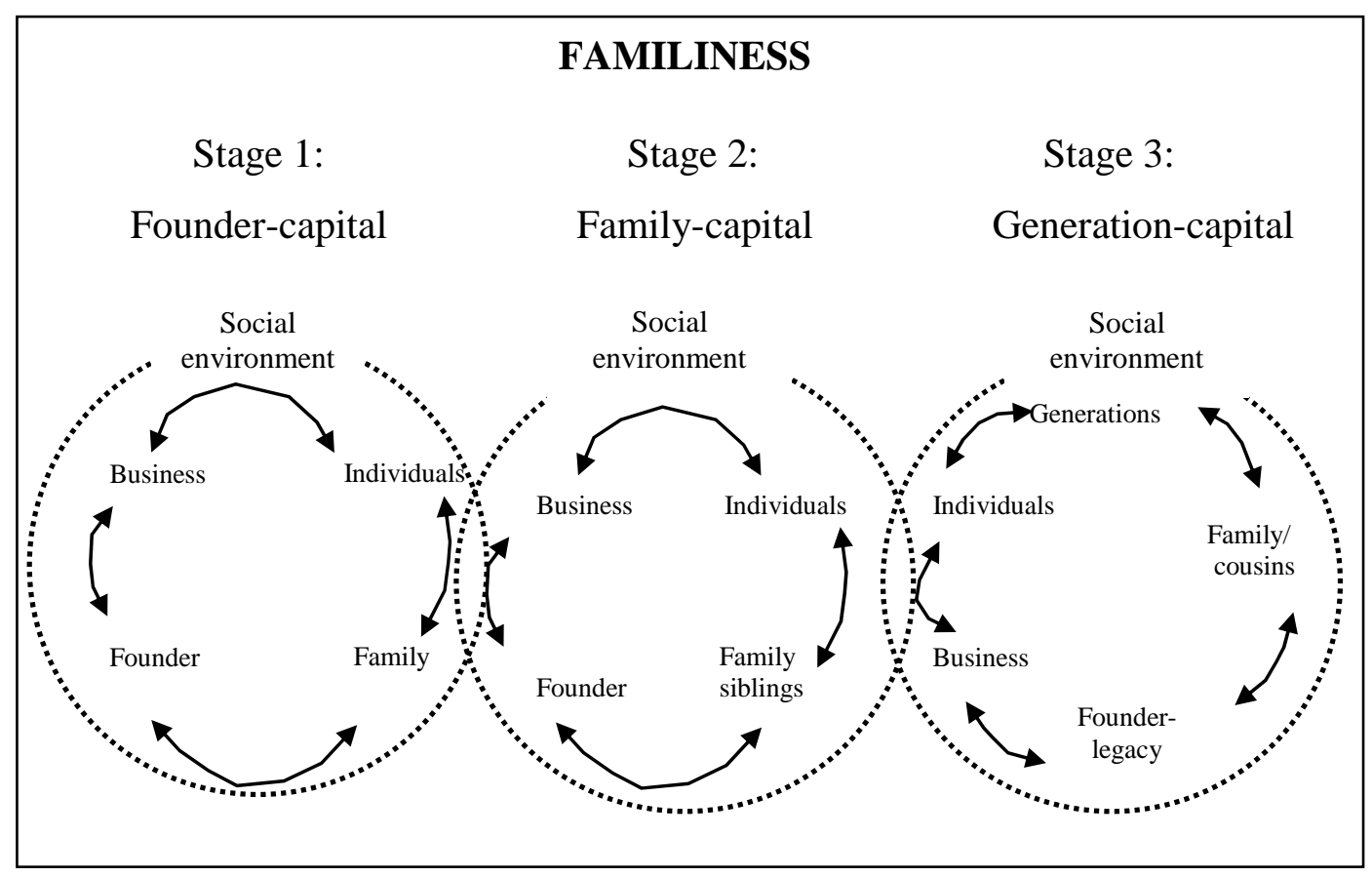

Figure 1: Evolution of family- business

Source: Adapted from Venter, 2003: 98-100. 
Stage one in Figure 1 is a representation of the start-up phase of the family firm. During this early stage the founder is more occupied with the survival of the business than the long-term generational continuity. At this stage, the founder influences the rest of the family while a reciprocal relationship develops among the founder, the family, individuals, business and the social environment. The reciprocal relationships of the first stage will only create founder-capital and become distinctive if the business were to become successful to the extent that the descendants of the founder are inspired to join that business. During stage two, family-capital develops within the family as a result of founder-capital, but in conjunction with the other significant parties: the business, individuals in the business and the broader community. Should the family-capital be distinctive and aligned with founder-capital, the family business is ready to advance to the third stage, namely generationcapital. Distinctive generation-capital is developed by aligning founder-legacy with family-capital. The reciprocal relationship with the social environment is also acknowledged by Hoelscher (2002:27, 30) who refers to this relationship as social-capital. Hoelscher (2002:27, 30) argues that the different forms of capital found in the family-business group, result from the social connectivity among the family firm, its members and their connection with the socio-economic environment in which they operate. Community-level social-capital, generated by familycontrolled businesses in the form of shared empathy, problem-solving techniques and shared values, is a reason for the long-term survival of family businesses, notwithstanding the additional costs involved (Lester \& Canella, 2006:755). Social-capital seems to give family businesses an additional purpose to survive and to continue their altruistic support to the social environment.
Venter (2003:88) further suggests a framework for investigation into the continuity planning of the generational-transition of familiness in the form of founder-, family- and generation-capital that leads to superior business performance by the family firm as depicted in Figure 2.

Figure 2 forms the basis for this article, with the purpose of qualitatively determining the influence of familiness on the family-business performance. Ward (2004:32) warns that every generational stage of the family business will be challenged by its own confrontations, beliefs, visions and strategies. The owning family can act as either an opportunity or a threat for the family business, as illustrated in Table 2.

The implications of Table 2 above are that family-business owners should focus on both proximity and identity issues in order to become multi-generational (Schwass, 2005:46). It is advisable for a family tradition to be developed through extensive participation by family members in the family business, with discussions focused on succession planning (Ward, 2004:64; Poza, 2007:5). Dr Raymond Ackerman, founder of Pick n' Pay, believes that succession planning for the younger generation is in the company's greater interest (Prichard, 2004:317). The step-by-step model suggested by Venter (2003) provides resolutions for the concerns of authors like Bornheim (2000), Rock (1991) and Ward (2004). The following three consecutive models, representing three stages of transmission of familiness, are suggested by Venter (2003:98-100):

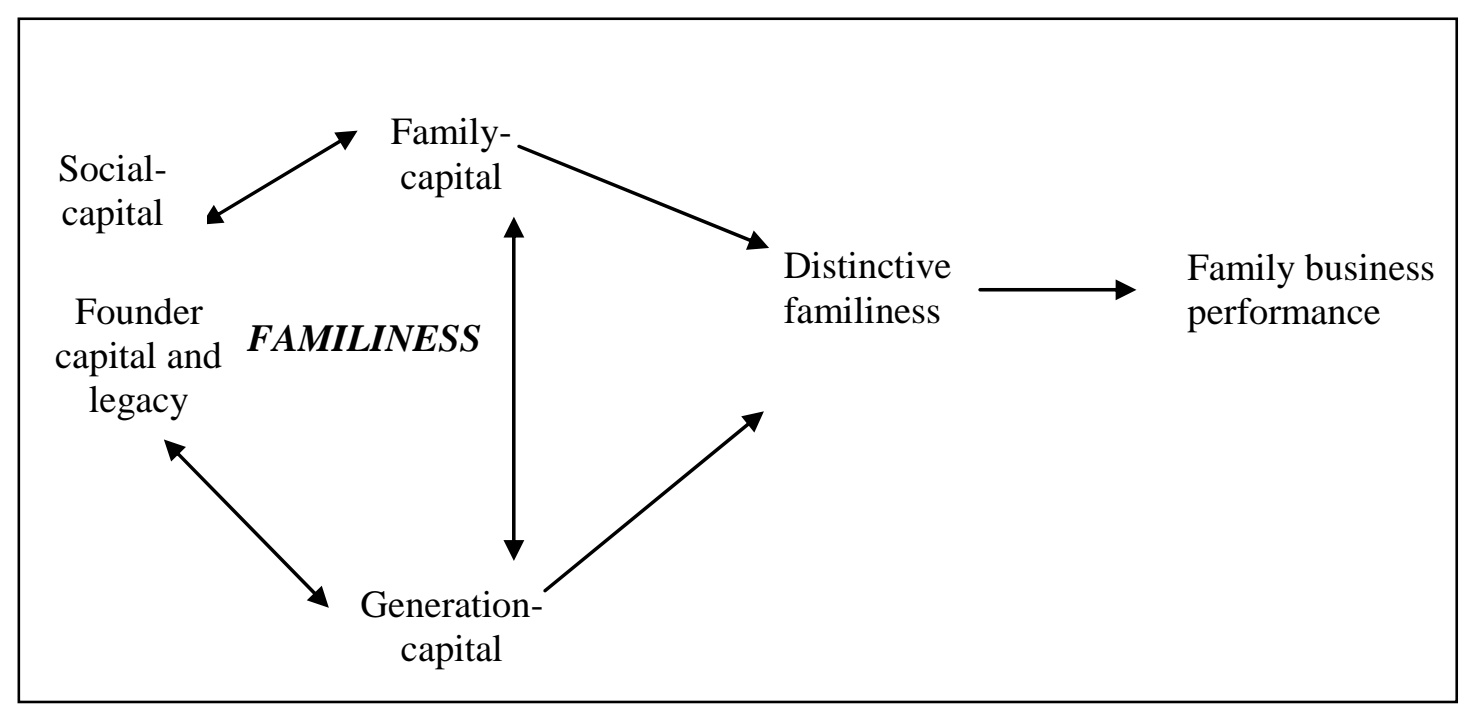

Figure 2: Framework of distinctive family business performance

Source: Adapted from Venter, 2003: 98-100. 
Table 2: Opportunities and threats created by the owning family in family businesses

\begin{tabular}{|c|c|c|}
\hline & Proximity & Identity \\
\hline Opportunity & $\begin{array}{l}\text { - In-depth and historic knowledge of the business } \\
\text { institutional memory } \\
\text { - Strongest interest in financial success of the } \\
\text { business }\end{array}$ & $\begin{array}{l}\text { - } \begin{array}{l}\text { Tangible forms of reference, including 'the } \\
\text { buck stops here' }\end{array} \\
\text { - The values enacted by the family }\end{array}$ \\
\hline Threat & $\begin{array}{l}\text { - Not qualified and competent } \\
\text { - The financial interest too individually biased: } \\
\text { 'milking the business' }\end{array}$ & $\begin{array}{l}\text { - The family identity limiting business } \\
\text { opportunities } \\
\text { - The values not being supportive of the business }\end{array}$ \\
\hline
\end{tabular}

Source: Adapted from Schwass, 2005:46.

\section{First stage - first generation}

Venter (2003:98) indicates that during the first stage, the founder creates a culture which is transmitted to the rest of the business, eventually influencing the performance of the business. The different parties involved in stage one are represented in Figure 3 (Venter, 2003:98).

The first stage is the developmental phase of the owner or the founder of the business, whose goal it is to maximise shareholder value of the enterprise (Venter, 2003:97). Venter (2003:98-99) explains that transmission takes place from the founder (channel 1) through all the succeeding channels, eventually influencing business performance (channel 2). Through a process of internalisation, topmanagement (channel 3) adopts the culture, values, beliefs and actions of the founder before transmitting them to the rest of the organisation (channel 4). Internalisation is defined by Plug, Meyer, Louw and Gouws (1986:161) as the process through which individuals make the values, opinions and attitudes of others part of their own belief system and act accordingly. Venter (2003:110-111) refers to this process of internalisation as a filtering process by which significant information and cultural values are taken through mental models of individuals and transmitted to others.

With the closer and more regular contact that topmanagement has with the founder, top-management are regarded as a distinctive transmission channel in the family firm. The founder may also directly influence the business, referred to by Rowe (2001:81) as strategic leadership, thereby conveying both managerial and visionary leadership to the business (channel 5). Though the founder's children may be too young to join the business, the founder can generally exert his influence on them, shaping their identity, values, skills and behaviour (channel 6). The seventh channel indicates the influence of the business on the unique performance of the family business, while the eighth channel represents the reciprocal influence between the performance of the business and the social environment.

\section{Second stage - second generation}

Venter (2003:99) describes how founder-capital and familycapital, with the acknowledgment of all the other parties, can become an influential force in the performance of the family business in the second generation. As shown in Figure 4, the second stage of the family business also acknowledges the transmission channels of the first stage. Additional to this stage, is the inclusion of family-capital in order to concentrate more on the children of the founder becoming an influential force in the family business (Venter, 2003:99) as depicted in Figure 4.

As illustrated in Figure 4 the family internalises the influence of the founder (channel 9) and transmits it to the corporate culture (channel 10), top-management (channel 11) and the rest of the business (channel 12). This is a dynamic process in which innovative changes have to take place in order for the business to keep growing. The dotted line represents the process of the development of familycapital in the business, while environmental conditions and relationships with external stake-holders are acknowledged.

\section{Third stage - third generation}

The third stage has to do with the transmission of familybusiness capital from the founder's children to the larger, extended third generation. Generation-capital is defined for the purposes of the current study, as the present value of the family's future entrepreneurial and managerial resources that the generations inherit, amend and recreate for the benefit and prosperity of the family business, as illustrated in Figure 5.

Venter (2003:100) indicates in Figure 5 that once the founder leaves the business, instead of founder-capital, it is a founder-legacy that is inherited, absorbed and internalised in the family business. This continues to influence subsequent generations (channel 13). Similarly, the older generations of the founder's descendants influence the younger generations, forming generational-capital (channel 14). Younger generations, in turn, internalise the founderlegacy and family-capital beliefs and values in the business culture, simultaneously acknowledging social-capital structures.

It seems from Figure 5 above, that all the stages in the formation of family-business capital, namely those of founder-, family- and generational-capital in relation to the social environment and the forming of social-capital structures, are important forces in the evolution, long-term survival and prosperity processes of the family business. 


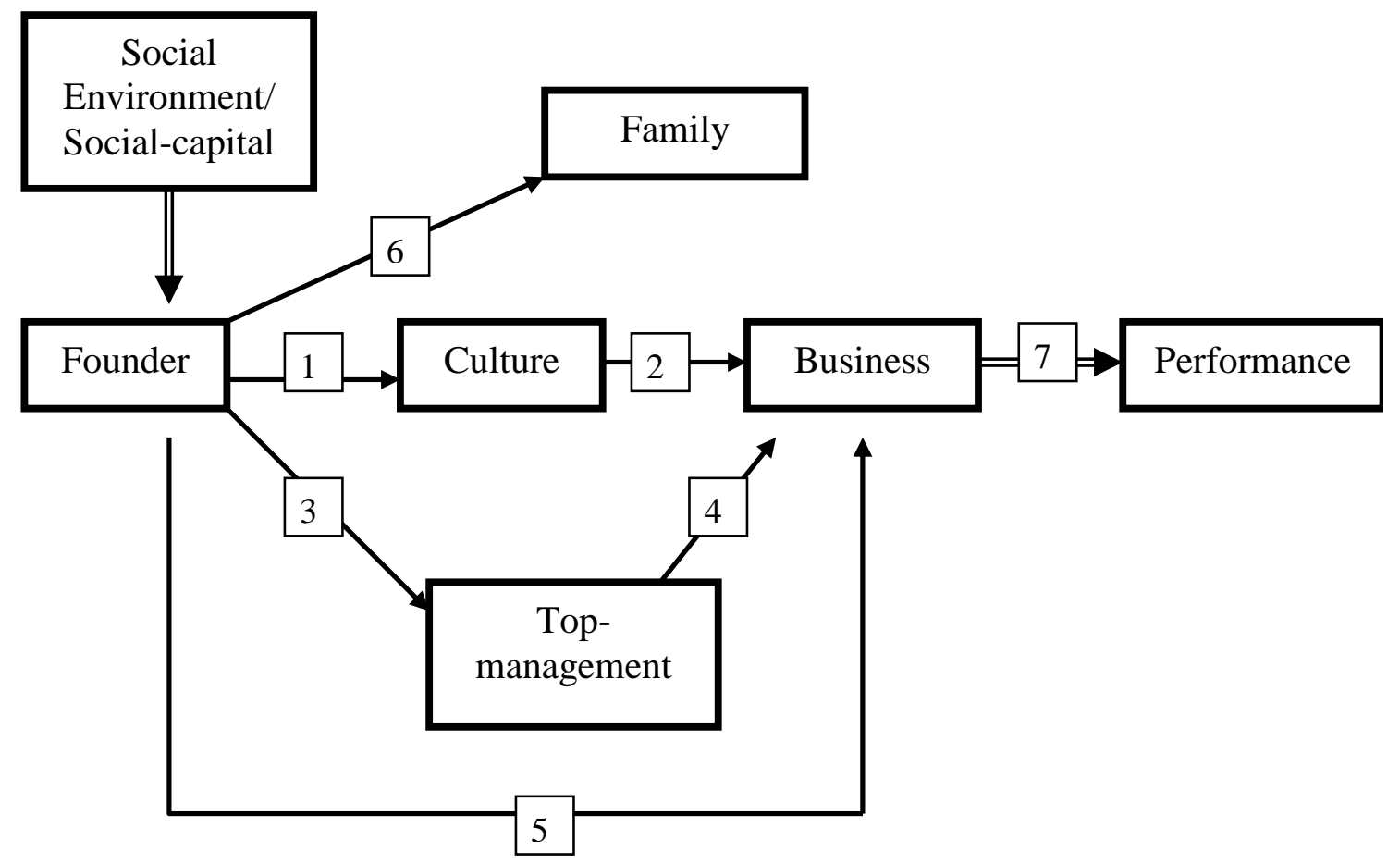

Figure 3: Creation and transmission of familiness in stage one - founder-capital

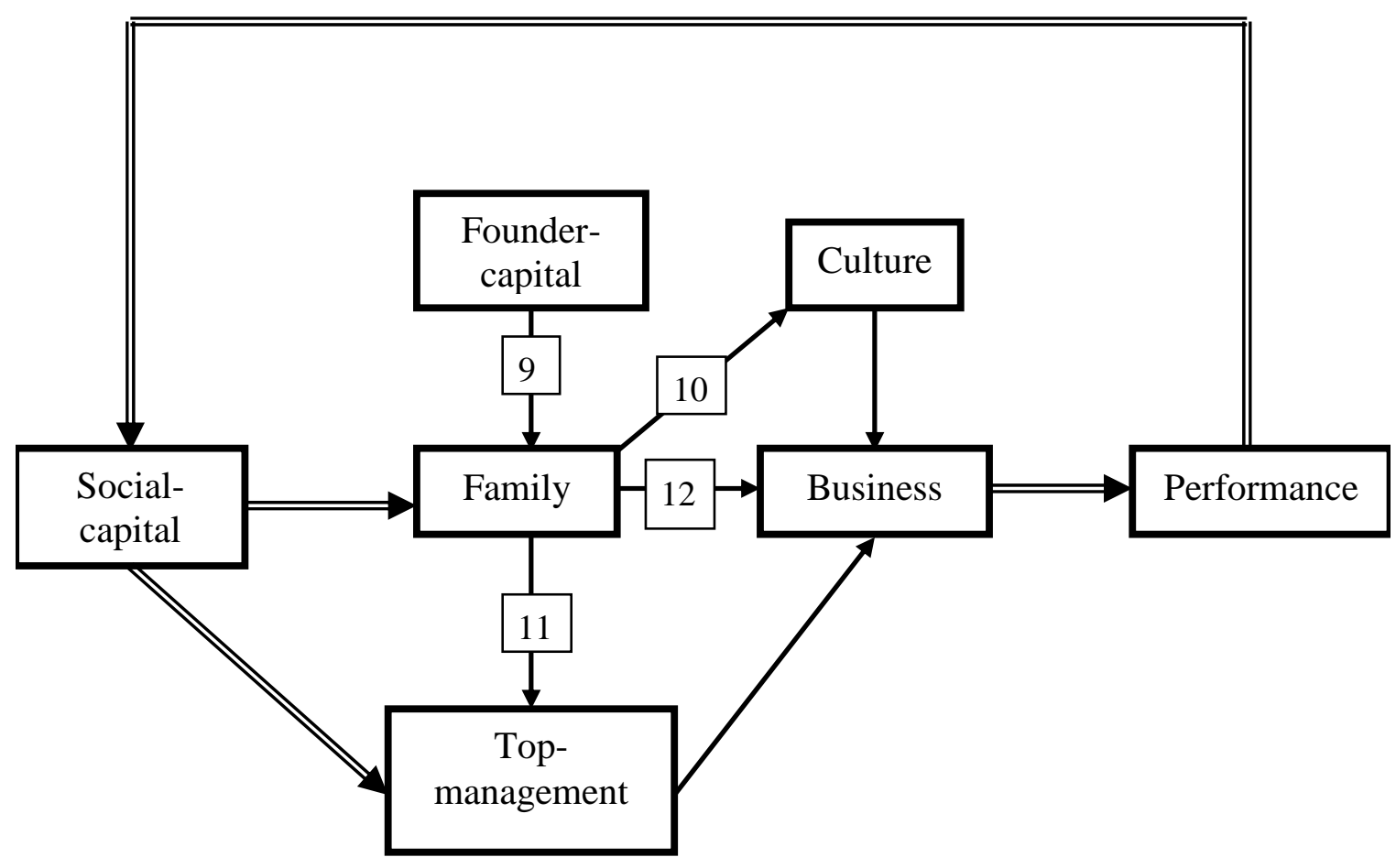

Figure 4: Creation and transmission of familiness in stage two - family-capital 


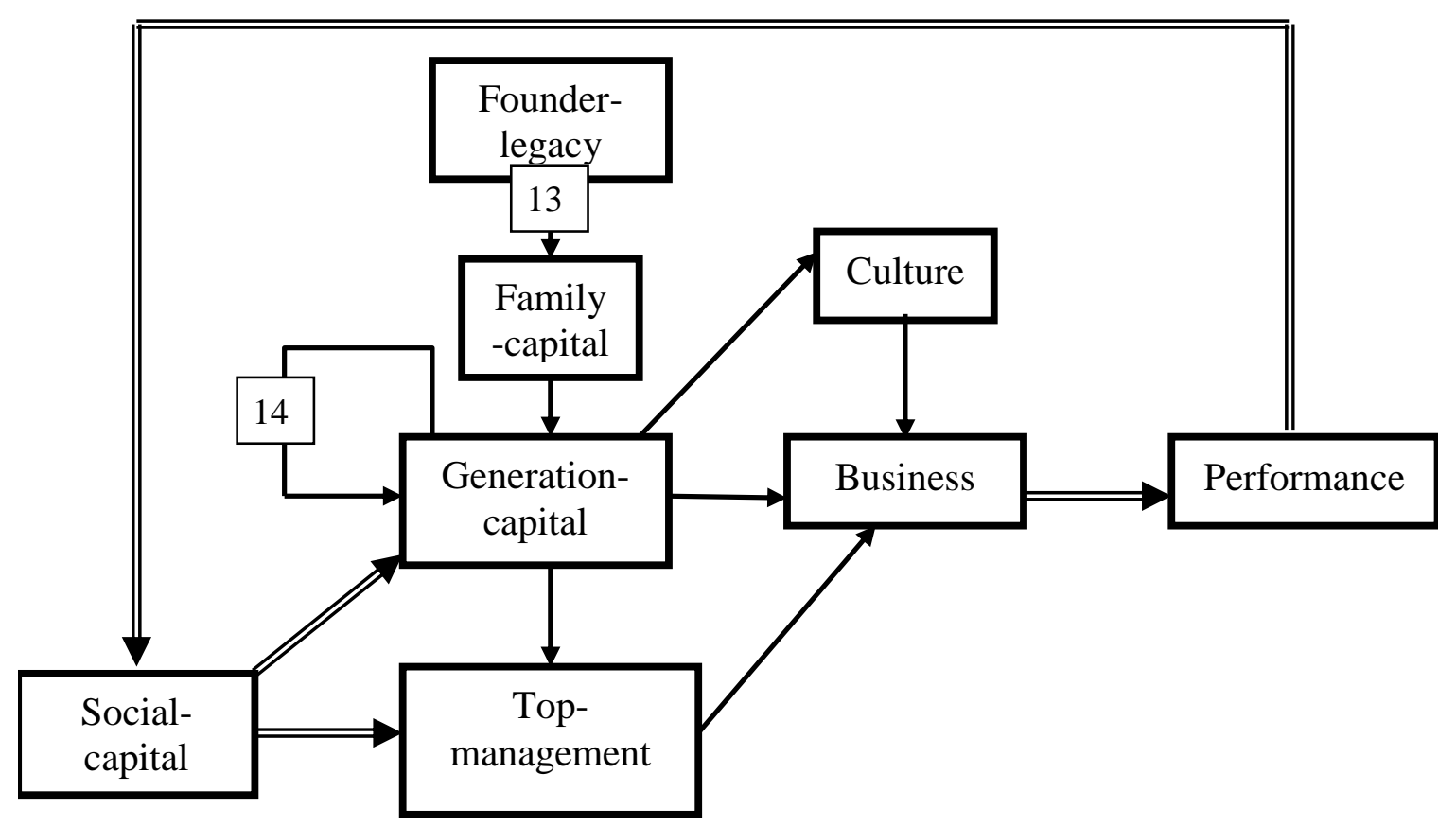

Figure 5: Creation and transmission of familiness in stage three - generational capital

\section{A conceptual familiness transmission of capital model}

Based on Venter's (2003) investigation as described in paragraph 1.3 above, the current research poses to investigate the transmission of familiness that takes place in the different evolutionary stages and channels of the family business. The term 'transmission of capital' is used to investigate the process of exchange among the three forms of capital, i.e. founder-, family- and generation-capital, as the means by which familiness creates superior business performance. Since familiness and the different forms of family-business capital are discussed as a unified system, it is difficult, if not impossible, to separate the different channels.

\section{Stage one: Founder-capital}

Founder-capital is established during stage one. Foundercapital is defined as the present value of the founder's future entrepreneurial and managerial resources that are harnessed for the benefit and prosperity of the family business. Founder-capital will relate to the entrepreneurial capital concept of Erikson (2002:278) that regards both entrepreneurial competence and commitment as playing an important part in the success of a business.

In family businesses, the influence of the founder seems to continue through generational transition. Five unique functions of founders are identified by Schein (1983:25-28), namely:

- the absorption and control of risks and concerns that accompany it;

- the stimulation of innovation;
- $\quad$ the cultivation of motivation;

- the establishment of values and principles in the business; and

- The creation of a continuous evolution of the business by means of regeneration.

Chandler and Hanks (1994:78-79) regard the founder as fulfilling the roles of both manager and entrepreneur. Where founders scan the environment as entrepreneurs, to assess opportunities and strategies, these founders interact with the environment as managers to exploit exceptional resources, co-ordinate such resources, program development, evaluate performance and motivate employees.

In the following section the specific channels during the phases of founder and family-capital are discussed, following the careful appraisal of 66 independent interviews which were conducted at Altron, a large South African family-business. Generation-capital was not investigated as the business under investigation was only in the second generational stage.

Stage one, channel one: The founder-to-culture channel

Venter (2003:101) explains that this channel refers to the determining influence the founder has on the familybusiness culture. The founder's 'theory of success' often becomes firmly embedded in the culture of the business, especially when the initial crises of survival and growth have been successfully overcome.

From the 14 interviews conducted with the founder, the founding group and early employees it is reported that the 
founder of Altron made use of intensive and extensive, informal methods for transmitting culture while exercising both formal and informal controls in being 'people orientated' and promoting 'attention to detail' (Venter, 2003:159-164). The original formation of the culture was done principally on a personal contact basis, but as the organisation grew, formal methods had to be applied. Leading by example was indicated through demonstratively hard work, late hours and the taking of two briefcases of work home each evening, yet not expecting individuals to do work that he himself could not do. With the founder setting the example, employees get the impression that the same is expected from them. Paying attention to detail emphasised the importance of close scrutiny of both major and minor issues, thereby establishing a culture of thoroughness, professional conduct and people orientation. Informal controls refer to information gained through informal channels, like the principle of 'Management by Walking Around' and an 'open-door policy'. This allows for a continual check on the quality of work done, neatness, diligence and accuracy, so that corrective action may timeously be taken. Formal controls were based on key business variables as identified by Geneen (1984), explaining that top managers have to report on a monthly basis at review meetings, where every aspect of business performance is measured. Communication was optimised by regularly and clearly sharing information on values and expectations, praising good work, setting objectives and motivating employees to meet strategies. Human resource practices were employed as a tool to reward individuals who performed to expected standards. Social integration was accomplished through factory visits and informal functions, such as the Young Presidents' Club (YPC) meetings. Physical space was addressed by ensuring a neat and inviting work environment with a professional finish. The organisational structure was quick and efficient, facilitating quick decision-making processes and the rapid implementation of the conclusions reached.

Stage one, channel two: The culture-to-business channel

Channel two has to do with the institutionalisation of a process whereby new employees are socialised into the family-business. The founder and his family play a more indirect role in the socialisation process. The institutionalisation of the larger group-culture is especially important in respect of successfully integrating newlyacquired companies. The founder, top-management and HR managers were interviewed concerning the culture to business path.

The results of the 14 interviews indicated that a hardworking, above average customer orientated, performance, is more likely to fit into the family-business group culture. It is emphasised that employees need to work in a formal structure to channel their professionalism, discipline and entrepreneurial energies. Informal assimilation was reported as the main method used by the founder, family and topmanagement to communicate corporate culture to the business. This was done through regular visits to companies, as well as through review meetings, awards functions and empowerment projects. Financial discipline is a particularly strong factor in the establishment of the culture of this family-business group. The alignment of policies and procedures with the holding company is one of the first actions that take place with the acquisition of a new company. This is achieved in the same manner as the founder transmits his culture in the first stage, channel one. Communication is conducted by a formal Corporate Relations department, responsible for design, publishing and distribution of in-house magazines, annual reports, awards by the company, as well as formal and informal functions. Functions and awards are significant motivational events, always addressed by the founder, second generation managers and top-management of the family-business group. Speeches reveal the secrets behind the success of the company, the challenges ahead, all with the expectancy that an internalisation of the values of the company will take place. Formal social integration and assimilation is not standardised across the company, but in some cases orientation lasting between one and three days takes place. During these exercises, the culture of the company is shared through Annual Reports, newspaper-cutting scrap books, newsletters, company memos and videos of awards functions and other company events. Example and demonstration is mainly used when the holding company (Altron) engages in acquisitions, by demonstrating the sophisticated and professional organisation of the holding company, and by creating opportunities in which the acquired entities can participate, such as the attainment of awards.

Stage one, channel three: The founder-to-topmanagement channel

Channel three mainly has to do with the transmission of values from the founder to top-management. The founder and senior family members seem to be the hub through which profitable relationships are formed with outside decision-makers and potential clients. This centrality has, however, shifted in later years to the managing directors and descendants of the founder. Answers to the questions in this channel were directed to the founder and corporate topmanagement.

The 14 interviews revealed the founder was supportive of independence and competence as well as intrapreneurship, to the point that it does not disagree with the vision of the founder. Deviation from the founder's vision would therefore not normally be tolerated. The founder would especially be a motivational agent by coaching and cultivating his managers to understand, accept and practise the values and theories of his success while inspiring them to meet high standards of excellence.

\section{Stage one, channel four: The top-management-to- business channel}

Channel four has to do with the way in which topmanagement transmits the culture of the business to the rest of the organisation. As the family-business group (Altron) consists of over 100 operating companies and 13000 employees, it is not surprising to find slight cultural differences transmitted by top-management as well as a dilution of the culture at lower levels in the group. The 
founder as well as current top-management in both the corporate and operational spheres of the business was interviewed.

The 14 interviews conducted revealed that an internalisation process takes place through communication in the form of monthly review meetings, a detail-orientated management style as well as informal discussions, in the form of afterwork gatherings (Venter, 2003:174-176). Strategic management seems to have been more informal and opportunistic, but has lately become more formalised. Control of performance is achieved through a 'sign-off' or 'follow-up' method. A dedicated commitment to the group, and sound customer relations through leading by example, are revealed by top-management.

Stage one, channel five: The founder-to-business channel

Channel five has to do with any ancillary influences the founder may have on the performance of the business. Eight (8) interviews with the founder and corporate topmanagement indicated that apart from other channels where the founder transmits his influence through the culture of the organisation and through top-management, the active involvement of the founder leads to the direct impact and transmission of influence in the business. The factors that significantly describe the influence of the founder on the business, reside in this channel. These suggest direct involvement in the business, more specifically in certain tasks and the creation of new business, with the motivation of individuals done in a way that creates ultimate loyalty, with a willingness to '... give everything...' A keen interest is shown in employees through direct involvement with them and by demonstrating concern for their welfare. By inspiring loyalty as well as by creating confidence, individuals are encouraged to explore their abilities to the utmost. The founder reportedly has an ability to interpret and understand people behaviour, quickly understanding what motivates them and accordingly being able to build their confidence. Attention to detail is practised by ensuring that standards are kept at the highest levels of professionalism. In addition, members of the familybusiness group are encouraged to acquire a wide knowledge, to cultivate an ability to assess business products accurately, as well as an instinct for spotting viable business opportunities. The founder also reportedly acts as rolemodel for most employees, leading the way in even the most humble of tasks, simultaneously setting a standard of excellence, pursuing goals, exemplifying an excellent sales and marketing person, while also being entrepreneurially competent. The founder shows a clear vision and acts in response to his foresight. The founder is further described as appointing the right people to perform tasks to the highest standard. A culture of sportsmanship is promoted by the founder through the creation of a fun-like atmosphere. Simultaneously, however, the founder demonstrates personal power through his strength of mind, always requiring the highest standards of performance.

Stage one, channel six: The founder-to-family channel transmits values to descendants before them joining the business. Fourteen (14) interviews were conducted with the founder and descendants (relevant family members). Family, friends and siblings agreed that the founder always gave them freedom of choice concerning their career paths as well the right to make most of their own decisions. Siblings were encouraged to do what they believed would please them career-wise and also to develop and fulfil their potential. The founder cultivated significant levels of self discipline in his children, by encouraging them to set ambitious goals, to earn their own pocket-money, to support themselves and not only spend money, but to save it too. He discouraged them from allowing wealth to go to their heads, pointing out that that they are effectively nobody until they have proven themselves to be someone of substance. Discipline was also instilled through values, praise, guidance, leading by example and constructive criticism. Resilience was forged in the children by the founder encouraging them to follow through on their aims and decisions, despite disruptive adversity and to learn to cope with pressure. The family was seen as part of the business, since business problems, solutions and successes were discussed and the children were encouraged to undertake holiday work at the company. Business was also part of family life; the children were involved in visiting the factories in order to observe quality, neatness and the company's product ranges. Quality time was also spent with the family to build healthy family relationships. The founder was seen as a strong disciplinarian, whose values were ingrained in his children through his guidance. The children were taught that they should not expect only to receive but should also be accountable and responsible for their thoughts and deeds. The children were also taught to feel and express appreciation their family connection.

\section{Stage one, channel seven: The business-to- performance channel}

No specific questions relating to non-financial performance of the family-business group under investigation were asked in the 30 interviews conducted. It emerged, however, that certain characteristics seem to play an important part in the performance of this family business. While swift and thoroughly researched business decisions are regarded as an advantage by this family-business group, they are tempered by an aversion to risk. In turn, however, risk aversion should never be elevated to the point where it stifles all opportunity, innovation and flexibility (Venter, 2003:278-281). An internal culture of intrapreneurship is nurtured in this family-business group, by encouraging individuals to seek and exploit external opportunities (Venter, 2003:151).

\section{Stage one, channel eight: The performance-to-social environment channel}

The family-business group undeniably functions in a social environment in which both giving and receiving takes place. Fourteen (14) interviews were conducted in this stage indicating social-capital interest and that the company's social responsibility engagements contributed meaningfully to many charities.

This channel addresses the way in which the founder 
Stage two: Family-capital

For the purposes of the current study, family-capital is defined as the present value of the future entrepreneurial and managerial resources that the family inherits, amends and recreates for the benefit and prosperity of the family business. It is essential that the founder-capital will be continued by the founder's descendants in the business as well as an increase in social-capital ventures.

\section{Stage two channel nine: Founder-capital-to-family channel}

At the second stage, founder-capital is firmly established in the business, and the founder-family association is not limited to the domestic environment but is also found in the business milieu (Venter, 2003:187-194; 115-117). From the 22 interviews conducted with the founder, relevant family members, and close employees it was evident that definite characteristics of the founder are observed in the children. The children are passionate about the founder, sustaining an ethos of excellence and leading others by example. The founder's managerial skills are respected and seen to be of a high standard. Although the siblings give attention to detail, just as the founder does, they have also developed their own management styles and are not regarded as clones of the founder. The siblings are seen as entrepreneurially innovative, while revealing a strong work-ethic, expecting high standards, leading by example and not entertaining prospects of failure. As the second generation, the siblings have a visionary perspective of being long-term orientated, seeking the big picture and setting goals. The potential for nepotism was avoided by for example good education which in turn gain the respect of managers. The children's personal expenses were never paid for by the family business. The children did not initially report to the founder, but had good and trusted managers who acted as mentors. These siblings seem to complement each other in the character and talent they contribute to the organisation; they are seen as excellent motivators by making others feel important; they are stern disciplinarians but uplifting in their approach, always giving appropriate, positive feedback and managing to get the best out of people. The second-generation siblings are further described as being compassionate, having good people-skills, being approachable and knowing how to motivate others. The siblings are also reported to be customer focused, making a point of promoting the business thoroughly to consumers. These siblings are also reportedly cost-conscious, showing an aversion to risk, and striving for the resolution of conflict.

\section{Stage two, channel 10: Family-to-culture channel}

The tenth channel has to do with the transmission of family values to the business culture. After succession, the founder, relevant family members and top managers were interviewed. After 30 individual interviews, it seemed that values and principles were important constructs transmitted by showing a strong work-ethic. This was established through conversations at meetings, personal contact, performance appraisal and the presentation of awards. Strong work-ethics are communicated by being fiercely competitive, but simultaneously setting high standards with intolerance to non-performance. Participative involvement is encouraged through open discussions, acting with integrity and sticking to commitments. Participation is further promoted by operating in an informal atmosphere, visits to facilities, as well as being actively involved and informed. The family culture is also reported to equate with the business culture, making employees feel they are part of the family and expecting intelligent conduct from them.

\section{Stage two, channel 11: Family-to-top-management channel}

The family's transmission of family-capital-to-topmanagement is investigated in channel 11, which focuses on the years of adversity and the succession process. For this purpose, the founder, corporate executives and senior managers were interviewed. Most of the 30 individuals interviewed indicated that the siblings earned the positions they held in the organisation and were well respected. It was observed that the siblings had been given well-deserved authority, and were fully in touch with, and in control of operations. A combination of autocratic and democratic management styles is reported. It was clear that the siblings are not controlled by the founder but work independently. A strong people orientation of tremendous inter-personal skills was observed, leading to a willingness among employees to walk the extra mile for the family. The family members led by example, showing high performance standards. Family members were also reported to motivate others, a visionary strategic management was observed and a culture existed in which performance was expected.

\section{Stage two, channel 12: Family-to-business channel}

It is clear that transmission of family-capital from the family to the business culture and top-management alone is not sufficient. Family-capital also needs to be transmitted to the business. The founder, successors, top corporate and operating managers, relevant employees and external stakeholders were interviewed. Certain advantages of familycapital appeared from the interviews.

From the interviews with 31 business managers, it followed that the family identity is not only the face of the business, but also serves as a form of stability that relates to the predictability, approachability, consistency, and mutual support from sibling management. Accordingly, this open relationship provides for a homelike feeling with a people orientation. In this channel, the significance of the whole business group is prioritised and valued, by being riskaverse, cost-effective and working in agreement with goals. It is appreciated that all significant parties are considered in the business-to-management relationship. The successors have formed an independence of character and are not overruled by the founder. It seems that conflict in the family is managed constructively with open, upfront discussions. Personal disagreements within the company appear to be a rarity. The values of the family are strengthened within the business through honesty, trust, commitment and plain hard work. Rapid decisions are made, as a result of correct reporting lines, high morale and the absence of corporate politics. A devoted customer orientation imperative is followed by involvement with and a deep understanding of, 
customer needs. These needs are satisfied with rapid and effective decision making. The family-to-business leadership is reported to be democratic, showing a culture of willingness to learn from others, being personally involved, and presenting a people-orientation commitment for the benefit of the family and the business.

\section{Stage three: Generation-capital}

Venter (Venter, 2003:100) depicts stage three as the transmission of founder and family-capital into generational-capital. The sample of investigation of the Venter (2003b) study did not include a third-generation family business. It was also the aim of the current study to investigate some third-generation family-business groups.

Stage three, channel 13: Founder-legacy-to-business channel

This stage and channel has to do with the transformation of founder-legacy to the business, leading to enhanced business performance.

Stage three, channel 14: The generation-capital channel

Channel 14 of the third stage relates to the attempts of the older generation to groom the younger generation to be successful recipients as well as transmitters of founder- legacy and family-capital, thereby maintaining familiness, but with a unique, transformed character. Because of the reciprocal relationships in the unified family-business system, it is impossible to separate the different factors that emerged in the discussion of the different stages, as they form an integrated whole.

\section{A Conceptual Familiness Transmission of Capital Model}

A new conceptual Familiness Transmission of Capital Model is proposed in Figure 6, combining all the channels represented in Figures 3, 4 and 5 into one figure, for easier reference. This conceptual model integrates founder, family, generational, business and social-capital into an interdependent, coherent entity.

This conceptual model implies that the various areas underlying the family business cannot be separated, but form an integrated whole. Conceptual modelling is described as three continuing dialogues, namely (1) the distinction between important and unimportant concepts; (2) the differentiation of the concepts, of the characteristics they have and do not have; and (3) the possible existence or nonexistence of relationships among the different concepts (Soulliere, Britt \& Maines, 2001:254-255).

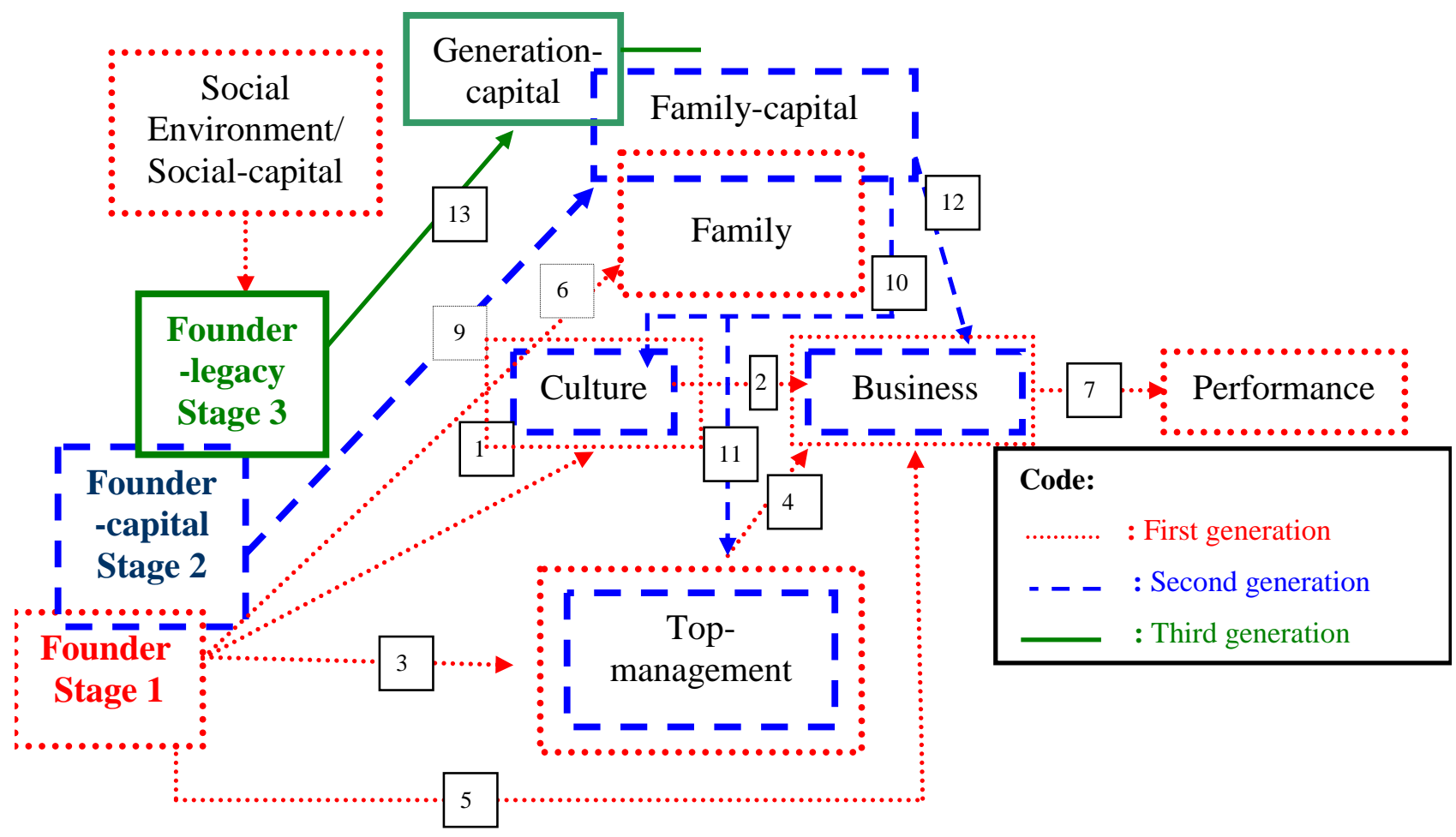

Figure 6: A proposed familiness Transmission of Capital Model revisited 
The fourteen transmission channels, as proposed in Figure 6 are aimed at answering the following seven questions set by Weigel (1992:126-128) underlining the quality of a conceptual model, namely:

Question 1: Does the model fit, or can it be modified to fit models that are related? As discussed in this article, and conceptualised in Figure 6 the three generation stages in the utilization of familiness and the transmission thereof, as it originates from the founder, branches out into fourteen different transmission channels.

Question 2: Are all possible, salient variables acknowledged?

The fourteen different channels are not a representation and simulation of reality, but rather a depiction of the important pathways in which reciprocal relationships among different main-role players are depicted, leading to the successful transmission of family-business capital through familiness.

Question 3: Are there any limitations in the proposed conceptual model?

The limitation of the model is seen in its inability to represent all the possible facets of reality. However, the strength of the model is the identification of the main roleplayers in the transmission and sustaining of family-business capital by means of familiness.

Question 4: Are verifiable research questions stimulated by the conceptual model? The different transmission channels depicted in Figure 6 are in themselves a proposed manner in which the transmission of capital, through familiness, is sustained. By providing answers to questions on each of these fourteen channels, the viability of the role of familiness in the transmission of capital is investigated.

Question 5: Does the proposed conceptual model adhere to the following three depicted guidelines for conceptual model development?

(i) Does the conceptual model or comply with existing knowledge? The literature discussion indicates that the proposed model complies with the literature review.

(ii) Is the conceptual model similar to the phenomena it represents? The different main-role players in the conceptual model are supported by the literature.

(iii) Does the conceptual model produce questions, propositions or hypotheses? All fourteen proposed channels lead to specific research questions. It further lead to the fourteen propositions

\section{Question 6: Are any indications for future research} exposed by the model?

The results of findings in the current study should in future be measured in different samples and different countries as well as in industries different from that of the current study. The results should be compared with and interpreted in respect of the findings of the current study, which should either confirm or reject the existence of the channels identified in the current study.

Question 7: Does the conceptual model provide strategies for intervention?

Each of the fourteen channels proposed by the conceptual model can serve as strategies of diagnosis and intervention. Interventions could be custom-designed to deal with diagnosed weaknesses in specific channels of family businesses.

It is concluded that the proposed conceptual model complies with the criteria prescribed to fulfil the function of conceptual modelling, as requested by Weigel (1992:126128).

\section{Conclusion}

The purpose of this article was to review the different theories underlying family businesses. It is concluded that the orthodox theories, that regard the business and the family as separate units, do not acknowledge the complexity of the different relationships that exist in family businesses. A Conceptual Familiness Transmission of Capital Model is proposed in the current study as representative of the functioning of family businesses as an interactive system. It embraces the heterodox views that the family and the business cannot be separated, but are rather seen as an interactive system with unique, collectable resources. It fulfils the need of the main deficiency in the family organisation literature, according to Bornheim (2000:163), namely a theory that explains the developmental stages of each generation succession.

\section{References}

Anderson, R.C. \& Reeb, D.M. 2003. 'Founding-family ownership and firm performance: Evidence from the S\&P 500', Journal of Finance, 58(3):1-37. [online] URL: www.afajof.org/pdf/forthcoming/ff_Ownership.pdf Accessed 2002-12-20.

Argyris, C. 1953. An introduction to field theory and interaction theory. New Haven, CN: Yale University Labour and Management Centre.

Bornheim, S.P. 2000. The organisational form of family business. Dordrecht: University of St. Gallen.

Carlock, R.S. \& Ward, J.L. 2001. Strategic planning for the family business: Parallel planning to unify the family and business. New York: Palgrave.

Chandler, A.D. (Jnr). 1990. Scale and scope: The dynamics of industrial capitalism. Cambridge, MA: Harvard University Press.

Chandler, G.N. \& Hanks, S.H. 1994. 'Founder competence, the environment, and venture performance,' Entrepreneurship Theory \& Practice, 23(4):19-39.

Chrisman, J.J., Chua, J.H. \& Litz, R. 2004. 'Comparing the agency cost of family and non-family firms: conceptual issues and exploratory evidence', Entrepreneurship Theory and Practice, 28(4):335-354.

Chrisman, J.J., Chua, J.H. \& Sharma, P. 2003. 'Current 
trends and future directions in family business management studies: toward a theory of the family firm'. [online] URL:www.usasbe.org/knowledge/whitepapers/chrisman200 3.pdf. Accessed 2005-08-08.

Chua, J.H., Chrisman, J.J. \& Sharma, P. 2003. 'Succession and non-succession concerns of family firms and agency relationship with non-family managers', Family Business Review, 16(2):89-107.

Church, R. 1993. 'The family firm in industrial capitalism: International perspectives on hypotheses and history', Business History, 35(4):17-43

De Geus, A. 1997. 'The living company', Harvard Business Review, 75(2):51-59.

Erikson, T. 2002. 'Entrepreneurial capital: The emerging venture's most important asset and competitive advantage', Journal of Business Venturing, 17:275-290.

Gersick, K.E., Davis, J.A., Hampton, M.M. \& Lansberg, I. 1997. Generation to generation. Boston: Harvard Business School Press.

Geneen, H. 1984. Managing. New York: Doubleday.

Gilmour, C. 2005. 'It's all in the bloodline', Financial Mail [online] URL:http://free financialmail.co.za/cgi. Accessed 2005-11-29.

Habbershon, T.G. \& Williams, M. 1999. A resource based framework for assessing the strategic advantages of family firms. Enterprising Families Initiative, Working Paper \#101. Pennsylvania: University of Pennsylvania.

Habbershon, T.G., Williams, M. \& Macmillan, I. 2001. A unified systems theory of family firm performance. Enterprising Families Initiative, Working Paper \#103. Pennsylvania: University of Pennsylvania.

Hoelscher, M.L. 2002. 'The relationship among familycapital and family business performance: collaboration and conflict as moderators'. Unpublished PhD thesis, Texas Technology University.

Kepner, E. 1983. 'The family and the firm: A coevolutionary perspective', Organisational Dynamics, 5(1):57-70.

Kreiser, P.M. 2001. 'Entrepreneurial organisation or family firm? A strategic analysis of Gulf States Paper Corporation'. Paper presented at $5^{\text {th }}$ EBHA Conference, 31 August to 1 September 2001, Oslo. [online]

URL://web.bi no/roskning/ebha2001 nsf. Accessed 200303-03.

Landes, D. 1965. 'Technological change and development in Western Europe. 1750-1914.' In Habakkuk, H.J. \& Postan, M.M. (eds.). The Cambridge Economic History of Europe, Vol VI (Part I). The Industrial Revolutions and After. Cambridge: Cambridge University Press, p.p. 274601.

Lansberg, I. 1983. 'Managing human resources in family firms: The problem of institutional overlap', Organizational Dynamics, 5(1):39-46.

Lester, R.H. \& Canella, A.A. 2006. 'Inter-organizational familiness: How family firms use interlocking directorates to build community-level social-capital', Entrepreneurship Theory and Practice, 30(6):755-775.

Lewin, K. 1997. Resolving social conflicts and field theory in social science. Washington DC: American Psychological Association.

Liang, T.W. \& Jek, G.J. 2000. 'The determinants of family business growth and performance in Singapore'. Working paper, Wharton-SMU. [online] URL: http://www.smu.edu.sg/research/ppapers.htm. Accessed 2002-11-24.

Litz, R.A. 1997. 'The family firm's exclusion from business school research: Explaining the void; addressing the opportunity', Entrepreneurship Theory and Practice, 21(3):55-71.

Neubauer, F. \& Lank, A.G. 1998. The family business: Its governance for sustainability. London: Macmillan.

Poza, E.J. 2007. Family business (2 ${ }^{\text {nd }}$ Edition). London: Thomson.

Plug, C., Meyer, W.F., Louw, D.A. \& Gouws, L.A. 1986. Psigologie woordeboek. (2de Uitgawe). Johannesburg: McGraw-Hill.

Prichard, D. 2004. Hearing grasshoppers jump: The story of Raymond Ackerman as told to Denise Prichard. Cape Town: David Philip.

Riordan, D.A. \& Riordan, M.P. 1993. 'Field theory: an alternative to systems theories in understanding the small family business', Journal of Small Business Management, 31(2):66-78.

\section{Rock, S. 1991. Family firms. Cambridge: Director Books}

Rowe, W.G. 2001. 'Creating wealth in organizations: the role of strategic leadership', Academy of Management Executive, 15(1):81-94.

Schein, E.H. 1983. 'The role of the founder in creating organizational culture', Organizational Dynamics, 5(1):1328.

Schwass, M. 2005. 'Family reckonings', New Zealand Listener, 158(2977):45-46.

Soulliere, D., Britt, D.W. \& Maines, D.R. 2001. 'Conceptual modelling as a toolbox for grounded theorists', The Sociological Quarterly, 42(2):253-269.

Tagiuri, R. \& Davis, J. 1996. 'Bivalent attributes of the family firm’, Family Business Review, 9(2):199-207.

Venter, W.P. 2003. 'The role of familiness in the performance of family-business groups'. Unpublished MPhil thesis. Johannesburg: Rand Afrikaans University.

Ward, J.L. 2004. Perpetuating the family business: Fifty lessons learned from long-lasting, successful families in business. New York: Palgrave MacMillan.

Weigel, D.J. 1992. 'A model of interaction in the intergenerational family business'. Unpublished MA thesis. Nevada: University of Nevada. 